УДК $378-047.22: 005.6$

(C) Друганова О. М., Мартиненко I. I., 2019 р.

http://orcid.org./0000-0002- 5985-8293

http://orcid.org./0000-0002- 7601-8835

DOI: $10.34142 / 23128046.2019 .46 .04$

О. М. Друганова,

I. I. Мартиненко

\title{
КЕЙС-ТЕХНОЛОГІЯ ЯК ЕФЕКТИВНИЙ СПОСІБ ПІДГОТОВКИ СУЧАСНОГО ВИКЛАДАЧА ВИЩОЇ ШКОЛИ
}

У статті розглянуто роль кейс-технологї у процесі підготовки сучасного викладача закладу вищиӧ освіти, подано аналіз ї сутності, складників ц̌ особливостей застосування. Доведено, щзо педагогічний потенціал технології надзвичайно великий. До переліку ї̈ переваг відносять: нову модель поведінки студента в навчальній діяльності - від пасивного засвоєння знань до активной, творчої, дослідницької самостійной й самоосвітньої діяльності, щзо підвищує пізнавальний інтерес, суттєво впливає на активізацію мислення й стимулює інтелектуальну діяльність, забезпечує кожному учасникові можливість побудувати власну траєкторію самоосвіти й взаємонавчання. Важливу роль у підвищенні ефективності формування професійної компетентності викладача вищуӧ иколи відіграє створення професійно-креативного середовища, яке максимально моделює професійну діяльність, надає можливість побути в реальній життєвій ситуації, «зануритися» й «прожити із нею певний час»; формує конкретні уявлення щзодо складності педагогічної праці, стає ефективним засобом розвитку професійних якостей магістра.

Виявлено, щзо упровадження кейс-технологї результативне тільки у тісній співпраці професорсько-викладацького складу зі студентами й лиме за умови ӥхньої мотивачійной готовності як до професійного саморозвитку, так $i$ до участі у такому навчальному занятті. Важливого значення набувають уміння викладача створити професійно-педагогічну ситуацію, визначити той комплекс знань, який необхідний для ї̈ розв'язання; його комунікативні здібності ц̌ якості, вміння розв'язувати й попереджати конфлікти. Від слухачів курсу «Педагогіка вищзї школи» робота над кейсом вимагає бажання вчитися по-новому, прагнення до самоосвіти. Важливого значення набувають також рівень сформованих у магістрів умінь проводити самостійну пошукову діяльність, навичок усного й письмового спілкування, вміння співпращювати у команді тощзо.

Ключові слова: компетентність, підготовка, кейс-технологія, викладач, заклад вищзої освіти. 
Druhanova O. M., Martynenko I. I. The case study technology as an effective way of a modern higher education teacher. The article considers the role of the case study technology in the process of developing of higher education teaching professionals and provides an analysis of its essence, components and peculiarities of its application. It is proved that the pedagogical potential of case study teaching is extremely high. The list of its advantages include a new model of students' learning behavior - from passive knowledge acquisition to active, creative, research-oriented independent self-education activities that boost cognitive interest, significantly affect the activation of thinking, stimulate intellectual activity and provide each student with an opportunity to build his/her own trajectory of self-education and learn from each other. An important role in improving the efficiency of the development of professional competence of higher education teachers is given to a professional creative environment which maximally simulates professional activities, gives an opportunity to deal with a real-life situation, "get engrossed" and "live through it for a certain time", leads to a clearer understanding of the complexity of pedagogical work, and becomes an effective means of developing professionally relevant qualities of Master's students.

The introduction of the case study technology is found to be effective, provided that there is a close cooperation between the teaching staff and students and on condition that the latter are strongly motivated for both professional development and participation in classes which involve doing case studies. The article places considerable emphasis on the ability of higher education teachers to create a profession-related pedagogical situation, determine the complex of knowledge necessary for its solution; emphasizes the significance of their communication skills and qualities as well as their ability to solve and prevent conflicts. Case study teaching requires that students taking the course "Pedagogy of Higher School" are willing to learn in a brand-new way and study independently. We also attach great importance to the level of skills that Master's students may find necessary to successfully conduct independent search activities, their oral and written communication skills, ability to work in a team, etc.

Keywords: competence, case study technology, teacher, higher education institution.

Вступ. Підвищення вимог до підготовки компетентнісних фахівців із різних галузей виробництва, які готові якісно й творчо виконувати свої посадові обов'язки, суттєво посилюють вимоги до професорськовикладацького складу закладів вищої освіти. Адже саме викладачі $є$ головним інноваційним потенціалом будь-якої країни, відповідальними за якість підготовки сучасних спеціалістів, готових до швидких змін і нових 
потреб ринку праці, до постійного саморозвитку і самореалізації упродовж усього свого життя.

Важливу роль у розв’язанні окреслених завдань спроможні відіграти новітні педагогічні технології, що змінюють навчальний процес, роблять його технологічним, прогнозованим i максимально наближеним до запланованих результатів. Серед широкої палітри сучасних технологій заслуговує на увагу кейс-технологія, що активно використовується в практиці підготовки фахівців із різних галузей, зокрема й у педагогічній, у багатьох країнах світу. Згідно з положеннями цієї технології, викладачем розробляється модель конкретної ситуації, яка має місце в реальній (чи видуманій) професійній практиці, та комплекс знань, практичних умінь i навичок, необхідних для їі реалізації.

Попри значну кількість статей із різних аспектів застосування кейстехнології, визначення іï переваг та обмежень у формуванні «індивідуального стилю професійної діяльності майбутніх учителів» (Shama, 2017), у підготовці «майбутніх викладачів до інноваційної професійної діяльності» (Kozak, 2015), у «оцінці й розвитку термінологічної компетентності майбутніх педагогів» (Bordovska, 2018 та ін.) вважаємо за необхідне зупинитися на проблемі визначення ролі кейс-технології у процесі підвищення якості підготовки майбутнього викладача закладу вищої освіти.

Мета та завдання. На основі вивчення наукових джерел обгрунтувати роль кейс-технології в процесі підготовки сучасного викладача закладу вищої освіти.

Методи дослідження. У процесі написання статті використано загальнонаукові методи (аналіз, синтез, узагальнення, порівняння тощо), що дозволило з'ясувати ступінь дослідженості проблеми, визначити сутність, складники й особливості застосування кейс-технології; розкрити вимоги до науково-педагогічних кадрів, що відповідають за підготовку майбутніх викладачів закладів вищої освіти. 
Результати. Основним завданням курсу «Педагогіка вищої школи», що відіграє важливу роль у підготовці сучасного викладача вищої школи, $є$ забезпечення оволодіння магістрами системою знань про концептуальні засади педагогіки вищої школи, озброєння їх широким спектром освітніх технологій, компетенціями педагогічного проектування освітніх програм, прогнозування змін у галузі освіти; формування прагнення до саморозвитку, до постійного професійного зростання й самовдосконалення в обраній сфері тощо.

Розв'язати поставлені завдання спроможні особистісно-розвивальні технології ситуаційного навчання, зокрема кейс-технологія, що базується на інтуїтивізмі, евристиці й персоналізмі, сприяє «напрацюванню особистісного підходу до отримання індивідуального результату, розвиває феноменологічне бачення галузей світу» (Khutorskoi, 2001).

Педагогічний потенціал технології кейсу, як свідчить дослідження, надзвичайно великий. У методологічному плані, як зазначають автори багатьох публікацій, у яких порушується вказана проблема (Л. Козак, В. Платов), кейс-технологію можна представити як складну систему, в яку інтегровані інші, більш прості методи пізнання, що виконують свої функції, як-от: моделювання педагогічної системи, стан якої розглядається в окремий дискретний момент часу, системний аналіз, проблемний метод, розумовий експеримент, методи опису, класифікації, ігрові методи, мозковий штурм, дискусія тощо. Визначаючи переваги технології ситуаційного навчання, науковці, що займаються iï вивченням, передусім називають їі орієнтованість на «постановку питань», у той час як інші методи - на «рішення, що пропонуються» (Strekalova \& Beliakov, 2013).

На відміну від традиційних способів навчання, на яких слухач освітніх курсів отримує систематизовані знання й навички їх використання, цілі кейсу «більш широкі й більш амбітні» (Strekalova \& Beliakov, 2013). Так, ретельний розбір педагогічної ситуації, що пропонується у кейсі, розгляд варіантів рішень до неї, які відрізняються повнотою й докладністю, спонукають 
слухачів магістратури диференційовано й точно аналізувати усі умови, перевіряти гіпотези щодо факторів, що зумовлюють ситуацію; вчать виділяти важливі або другорядні аспекти проблеми, науково пояснювати фактори поведінки учасників ситуації, що склалася; перевіряти ефективність знайдених варіантів рішень тощо. Аналіз, синтез, абстрагування, узагальнення, сприяє підвищенню ефективності формування у магістра критичного педагогічного мислення, яке дозволить їм у майбутньому успішно здійснювати власну професійну діяльність.

До переліку переваг технології, що аналізується, дослідники відносять також активний стиль поведінки суб'єктів навчального процесу, сутність якого полягає у «включенні індивідуальної творчості суб'єктів навчального процесу в колективну творчу діяльність» (Surmin, 2002). Утворення такого освітнього середовища стимулює індивідуальну активність магістрів, сприяє отриманню ними задоволення від пізнання нового тощо. Адже, саме у співдружності, під керівництвом, 3 будь-якою допомогою, як зазначав відомий психолог Л. С. Виготський, «особистість завжди може зробити більше і розв'язати більш складні завдання, ніж самостійно» (Vyhotskyi, 1956).

Колективне обговорення студентами конкретної ситуації, що запропонована викладачем (усно або письмово), або рольове іiі розігрування, сприяє формуванню у майбутнього викладача вміння знаходити найбільш раціональні рішення іiї розв'язання, чітко формулювати й презентувати власну позицію, вносити доповнення, дискутувати тощо. Така «творча конкуренція, своєрідна ейфорія, захопленість, позитивні емоції, що закономірно виникають під час обговорення кейсу, дають насолоду мислячому креативному студенту» (Strelnikov \& Britchenko, 2013). Зауважимо, що педагог при цьому виконує роль диспетчера процесу співтворчості - генерує запитання, створює й підтримує дискусії в процесі навчання, спонукає магістрів активно аналізувати ситуацію, обговорювати та приймати рішення, фіксує відповіді. 
Важливо зазначити, що викладач, який читає навчальний курс, має добре розумітися на його змісті й міжпредметних взаємозв'язках; бути добре обізнаним у галузі психології, методики викладання у вищій школі; створювати на заняттях умови співпраці й конкуренції тощо. Наголосимо, що в технологіï case-study викладач, підбиваючи підсумки, здійснює аналіз не тільки правильності варіантів вирішення самої ситуації, а й самого процесу їх висунення, аргументації та обговорення. До його обов'язків входить: оцінити виступи як окремих студентів, так і модераторів груп, у які об’ єднуються магістри задля спільного розв'язання конкретної ситуації; виявити їх сильні й слабкі сторони; визначити теоретичні «прогалини» тощо (Prokopiv, 2017)

Важливу роль у підвищенні ефективності формування професійної компетентності магістра - слухача курсу «Педагогіка вищої школи» відіграє й створення професійного середовища, яке максимально моделює професійну педагогічну діяльність, дозволяє перевірити набуті теоретичні знання, власні переконання та упередження. Адже кейси, що пропонуються ілюстративні (практичні), навчальні, науково-дослідні - надають майбутньому викладачеві можливість побути в реальній життєвій ситуації, «зануритися» й «прожити із нею певний час»; формують конкретні уявлення щодо складності педагогічної праці й педагогічного такту; сприяють розвитку гнучкості професійного мислення й творчої діяльності, ознаками яких $є$ «педагогічне передбачування, прогнозування ускладнень у процесі спілкування, схильність до оптимального вибору спільних творчих дій» тощо (Pedahohichni tekhnolohii, 1995).

Наголосимо, що саме в такому середовищі складається система умов організації життєдіяльності майбутніх спеціалістів, що спрямовується на формування й розвиток у них цінностей, їхньої професійної позиції, професійного світосприймання, готовності шукати й знаходити рішення, відчувати їх правильність чи хибність, нести відповідальність тощо. Упровадження кейс-технології формує «почуття впевненості у собі, сприяє 
подоланню зайвої полохливості або надмірної самовпевненості» (Keis-metod, n. d.).

Упровадження й реалізація технології кейс-стаді, як свідчить аналіз наукових джерел, результативні тільки у тісній співпраці професорськовикладацького складу зі студентами й лише за умови їхньої «мотиваційної готовності як до професійного саморозвитку, так і до участі у такому навчальному занятті» (Shama, 2018).

Особливої значущості в розробці й активному використанні кейстехнології набуває вміння викладача створити професійно-педагогічну ситуацію, навколо якої відбуватиметься обговорення, а також визначити теоретичну «начинку» (Пітер Екман) - той комплекс знань, який необхідний для розв'язання вказаної проблеми. На основі узагальнення вимог щодо написання кейсу, презентованих на сторінках різних досліджень, зазначимо, що проблема, пропонована для аналізу, має бути: достатньо складною проте відповідати рівню теоретичних знань й умінь і навичок дослідницької роботи студентів - слухачів курсу «Педагогіка вищої школи»; інформативною та багатоплановою; мати декілька варіантів (альтернатив) рішення; бути емоційно напруженою, провокувати дискусію тощо. Варто брати до увагу й рекомендацію фахівців із кейс-технології щодо доцільності врахування при укладанні кейсу національних ознак; необхідності вчасного оновлення змісту кейсу відповідно до нових умов та соціальних вимог тощо.

Важливого значення має й уміння викладача іти на перегляд, зміну й розвиток власних уявлень й планів, що $\epsilon$ свідченням його професійності. Адже магістри, які вирішують конкретну ситуацію, можуть отримати освітні результати, які не співпадають із тими, які очікує викладач курсу. Шлях вирішення нестандартної ситуації, що утворилася й яка являє собою суперечність між освітнім продуктом того, хто навчається та знаннями, норами та способами діяльності педагога, як зазначає А. Хуторськой, може полягати або у напрямі попередження виникнення такої ситуації, або подолання емоційного дискомфорту, що виникає, й підсвідомого бажання 
виключити його причину - усунути суперечність, що виникла між поглядами студента й викладача. Перший - полягає в конкретизації питань і задач, які обов’язково супроводжують кейс, й які визначать траєкторію їх вирішення у певному, потрібному напрямі. Другий - у сприйнятті «нестандартності» студентського продукту як закономірного й запланованого результату, переходу на стадію його добудови до цілісного вигляду (Khutorskoi, 2001).

Наголосимо, що викладач, який використовує кейс-технологію, мусить бути достатньо емоційний упродовж усього процесу навчання студентів, володіти емпатією - здатністю швидко й глибоко проникати у психологію тих, хто навчається, «емоційно ідентифікуватися 3 ними, інтегруватися в їхню активну цілеспрямовану спільну діяльність» (Keis-metod, n. d.).

Важливого значення в застосуванні кейс-технології набувають і комунікативні здібності, й якості викладача, вміння його розв’язувати й попереджати конфлікти. Адже емоційний фон у академічній групі при такій технології навчання, як зазначають дослідники, нагадує «вируючу плазму» (Keis-metod, n. d.). Зауважимо, що педагог, який активно практикує використання в процесі викладання навчальної дисципліни кейс-технології, не тільки максимально реалізує свої здібності, а й розвиває їх.

Від слухачів курсу «Педагогіка вищої школи» робота над кейсом вимагає, передусім, бажання вчитися по-новому, прагнення до самоосвіти. Важливого значення набувають також рівень сформованих у магістрів умінь проводити самостійну пошукову діяльність, знаходити й обробляти інформацію 3 різних джерел, співпрацювати у команді, презентувати результати власної навчальної й пошукової діяльності тощо та навичок усного й письмового спілкування.

Все це суттєво підсилює ефективність формування професійної компетентності магістрів і залучення їх до написання кейсів. Адже досвід самостійного моделювання педагогічних задач або ситуацій, як слушно зазначає Н. Саєнко, збагачує майбутніх викладачів вищої школи навичками професійної діяльності ще на етапі професійного навчання, формує «стійку 
педагогічну позицію як основу професіоналізму» (Saenko \& Bessmertnova, n. d.)

Обговорення. Проведене дослідження підтверджує результати досліджень вітчизняних і зарубіжних учених щодо ролі кейс-технології у підвищення якості процесу підготовки сучасного викладача закладу вищої освіти шляхом: а) зміни моделі поведінки магістра в навчальній діяльності від пасивного засвоєння знань до активної, творчої, дослідницької, самостійної й самоосвітньої діяльності; б) підвищення пізнавального інтересу, що впливає на активізацію мислення й стимулює інтелектуальну діяльність студента; в) формування у майбутнього викладача здатності вирішувати задачі, що визначаються умовами реальної професійної викладацької діяльності тощо.

Висновки. Таким чином, проведений науковий пошук дозволяє стверджувати, що застосування кейс-технології як способу підготовки сучасного викладача закладу вищої освіти сприяє: індивідуалізації освітньої взаємодії, розкриттю індивідуальних і творчих здібностей магістрів; усуненню розриву між теоретичною та практичною складовими професійної підготовки; формуванню педагогічної техніки, інформаційної й комунікативної культури. Перспективи подальших досліджень пов’язані 3 аналізом особливостей застосування технології кейс-стаді в процесі самостійної роботи магістрів - слухачів курсу «Педагогіка вищої школи».

\section{ЛІТЕРАТУРА:}

Выготский Л. С. Избранные психологические исследования. М. : Изд-во Академии педагогических наук РСФСР, 1956. 520 с

Кейс-метод. Окно в мир ситуационной методики обучения (case-study) [Электронний pecypc]. Режим доступу: www.casemethod.ru.

Козак Л. В. Кейс-метод у підготовці майбутніх викладачів до інноваційної професійної діяльності. Освітологічний дискурс. 2015. № 3. С. 153-162: Режим доступу: http://nbuv.gov.ua/UJRN/osdys_2015_3_17

Падалка О. С., Нісімчук А. М., Смолюк О. І., Шпак О. Т., Педагогічні технології. Навчальний посібник для вузів. К., 1995. 253 с., С. 180.

Платов В.Я. Деловые игры: разработка, организация и проведение: ученик. М.: Профиздат, 1991. 192 с.

Прокопів Л. Інноваційні технології навчання і виховання у ВНЗ: навчально-методичний посібник. Івано-Франківськ, 2017. 166 с. 
Ситуационный анализ, или Анатомия кейс-метода. Под ред. Ю. П. Сурмина. К.: Центр инноваций и развития, 2002. 286 с.

Стрельніков В. Ю., Брітченко І. Г. Сучасні технології навчання у вищій школі : модульний посібник для слухачів авторських курсів підвищення кваліфікації викладачів МІПК ПУЕТ. Полтава : ПУЕТ, 2013. 309 с.

Стрекалова Н. Д., Беляков В. Г. Разработка и применение учебных кейсов: практическое руководство [Текст]. Санкт-Петербургский филиал Нац. исслед. ун-та «Высшая школа экономики». СПб.: Отдел оперативной полиграфии НИУ ВШЭ СанктПетербург, 2013. 80 с.

Хуторской А. В. Современная дидактика: Учебник для вузов. СПб. : Питер, 2001. 544 с.

Шама I. Переваги та обмеження використання кейс-технології у процесі формування індивідуального стилю професійної діяльності майбутніх учителів. Науковий вісник Миколаївського національного університету імені В. О. Сухомлинського. Педагогічні науки. № 4 (59), грудень 2017. С. 542 - 547

Саенко Н. Р., Бессмертнова Н. А. Педагогические эффекты интерактивной технологии формирования банка кейсов в преподавании курса «Педагогика и психология высшей школы» для аспирантов Режим доступу: https://interactive-plus.ru/earticles/48/Action48-118183.pdf

\section{REFERENCES:}

Vyhotskii, L. S. (1956). Yzbrannye psykholohicheskie yssledovanyia. [Selected psychological research]. Moskva: Izd-vo Akademii pedahohicheskikh nauk RSFSR (in Russian).

Keis-metod (n. d.) Okno v mir sytuatsyonnoi metodiki obucheniia (case-study) [Case method. A window into the world of situational teaching methods]. Retrieved from: www.casemethod.ru. (in Russian).

Kozak, L.V. (2015). Keis-metod u pidhotovtsi maibutnikh vykladachiv do innovatsiinoi profesiinoi diialnosti. [Case method in preparing future teachers for innovative professional activities]. Osvitolohichnyi dyskurs. 3. 153-162. Retrieved from: http://nbuv.gov.ua/UJRN/osdys_2015_3_17 (in Ukranian).

Padalka, O. S., Nisimchuk, A. M., Smoliuk, I. O. \& Shpak, O. T. (1995) Pedahohichni tekhnolohii. [Pedagogical technologies]. Kyiv, 180 (in Ukranian).

Platov, V. Ya. (1991). Delovye ihry: razrabotka, orhanizatsiia i provedenie. [Business games: development, organization and implementation]. M.: Profizdat (in Russian).

Prokopiv, L. (2017). Innovatsiini tekhnolohii navchannia $i$ vykhovannia u VNZ. [Innovative technologies of education and upbringing in universities]. Ivano-Frankivsk (in Ukranian).

Surmyn, Yu. P. (Ed.) (2002). Situatsionnyi analiz, ili Anatomiia keis-metoda. [Situational analysis, or the anatomy of the case method]. K.: Tsentr innovatsii i razvitiia (in Russian).

Strelnikov, V. Yu. \& Britchenko, I. H. (2013). Suchasni tekhnolohii navchannia u vyshchii shkoli. [Modern technologies of teaching in high school]. Poltava : PUET (in Ukranian).

Strekalova, N. D. \& Beliakov, V. H. (2013). Razrabotka i primenenie uchebnykh keisov. [Development and use of case studies: a practical guide]. $\mathrm{CPb}$.: Otdel operativnoi polihrafii NIU VShE Sankt-Peterburh (in Russian).

Khutorskoi, A.V. (2001). Sovremennaia didaktika. [Modern didactics]. SPb.: Pyter (in Russian).

Shama, I. (2017). Perevahy ta obmezhennia vykorystannia keis-tekhnolohii u protsesi formuvannia indyvidualnoho styliu profesiinoi diialnosti maibutnikh uchyteliv. [Advantages and limitations of using case-technology in the process of forming the individual style of professional activity of future teachers]. Naukovyi visnyk Mykolaivskoho natsionalnoho universytetu imeni V.O. Sukhomlynskoho. 4 (59), 542 547 (in Ukranian).

Saenko, N. R. \& Bessmertnova, N. A. (n. d.) Pedahohicheskie effekty interaktivnoi tekhnolohii formirovaniia banka keisov v prepodavanii kursa «Pedahohika i psikholohiia vysshei shkoly». [Pedagogical effects of interactive technology of forming a bank of cases in 
teaching the course «Pedagogy and Psychology of Higher Education»]. Retrieved from: https://interactive-plus.ru/e-articles/48/Action48-118183.pdf (in Russian).

\section{Інформація про авторів: Друганова Олена Миколаївна: ORCID: http://orcid.org./0000 - $0002-5985-8293$, доктор педагогічних наук, професор, професор кафедри історії педагогіки та порівняльної педагогіки Харківського національного педагогічного університету імені Г.С. Сковороди, вул. Валентинівська, 2, м. Харків, Україна, 611666. \\ e-mail: druganova_lena@ukr.net}

\section{Мартиненко Іван Іванович: ORCID:} http://orcid.org./0000 - $0002-7601-8835$, кандидат педагогічних наук, доцент, доцент кафедри теорії і методики мистецької освіти та диригентсько-хорової підготовки вчителя Харківського національного педагогічного університету імені Г.С. Сковороди, вул. Валентинівська, 2, м. Харків, Україна, 611666.

e-mail: Martynenko20.01/63@gmail.com
Information about the authors:

Druhanova Olena Mykolaivna: ORCID: http://orcid.org./0000 - 0002 - 5985 - 8293, Dr. hab. in Pedagogy, Professor, Professor of History of Pedagogy and Comparative Pedagogy Department, H. S. Skovoroda Kharkiv National Pedagogical University, Valentynivska street, 2, Kharkiv, Ukraine, 61666.

e-mail: druganova_lena@ukr.net

Martynenko Ivan Ivanovych: ORCID: http://orcid.org./0000 - 0002 - $7601-8835$, $\mathrm{PhD}$ in Pedagogy, Associate Professor of the Department of Theory and Methodology of Art Education and Choir Conductor Training of Teachers, H. S. Skovoroda Kharkiv National Pedagogical University, Valentynivska street, 2, Kharkiv, Ukraine, 61666.

e-mail: Martynenko20.01/63@gmail.com

Цитуйте цю статтю як: Друганова О.М., Мартиненко I.I. Кейс-технологія як ефективний спосіб підготовки сучасного викладача вищої школи. Теорія та методика навчання та виховання. 2019. № 46. С. 48-58. DOI: 10.34142/23128046.2019.46.04

Дата надходження статті до редакції: 10.05.2019

Стаття прийнята до друку: 23.05.2019 